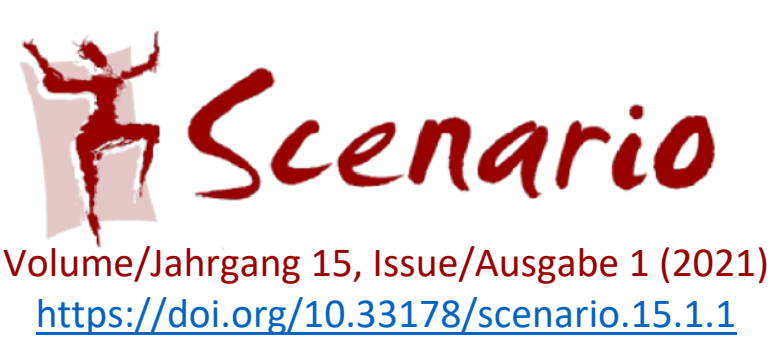

\title{
Perfect disguises
}

\section{Building an evidence base for improvisational drama}

\section{techniques}

\author{
Kristina Goodnight, Catherine van Beuningen, Rick de Graaff
}

Dutch secondary school pupils seldom speak the foreign language in class, citing anxiety as a primary factor (Haijma, 2013). Implementing improvisational drama techniques (IDTs), however, could help ameliorate this situation by generating positive affective reactions, such as confidence and joy, and in turn stimulate pupils to speak. The concept IDT in this study contains two key elements. Firstly, participants take on roles in fictitious situations. Secondly, the activities must elicit spontaneous speech as to offer language learners opportunities to practice real-life communication, which is central to the goal of this research. The question driving this study was: What types of IDTs induce positive affective reactions among pupils and, as such, have the potential to stimulate spoken interaction in FL classrooms? The study yielded 77 IDTs associated with positive affective reactions through a literature review and an analysis of student teacher reflections on their IDT use in their English classrooms. This combined evidence lends credence to the conception that it could be the essence of improvisational drama that generates positive reactions, rather than the type of activity-the essence being an invitation to enter a fictional world, combined with the improvisational element that readies learners for spontaneous interactions.

\section{Introduction}

\begin{abstract}
What was fun to see is that Martin and Pedro, who are both calm boys, really plunge into their role... I believe that this drama activity adds to the students' confidence of speaking English. I am a firm believer in joy. If students experience their lessons with joy then they are willing to overcome certain barriers. (Student Teacher)
\end{abstract}

After filming himself teaching an activity in which his pupils improvised a scene inspired by a picture, this student teacher reflected on his experience while taking the first author's English teacher training course Drama in the Curriculum (DitC). This student teacher, along with more than one hundred others who experimented with improvisational drama techniques (IDTs) for this course. While course participants often expressed initial reluctance to try out IDTs, these same student teachers found time and again that their secondary school pupils enjoyed doing the activities, gained confidence to speak the foreign language (FL). 
Like these student teachers, researchers worldwide have identified the power of improvisational drama in creating affective conditions optimal for spoken interaction, such as engagement (Atas, 2015) and confidence (Dunn \& Stinson, 2011). Affect has in fact been shown to play a key role in FL development (Arnold, 2018; Dewaele et al., 2018; Van Batenburg et al., 2020). Inspired by evidence from these studies and by the transformative experiences of the former DitC student teachers, a hypothesis emerged: training FL language teachers to use IDTs will foster regular integration of these activities in the classroom, and in turn, stimulate positive affective factors related to spoken interaction among their secondary school pupils. This hypothesis was strengthened in an earlier stage of this research, when interviews were conducted with former DitC student teachers at least one year after they had completed the course; eight out of nine were still implementing IDTs with some regularity.

We therefore embarked upon a longitudinal research project through which we are designing a professional development program (PDP) to test this hypothesis. In creating the content for the PDP, the quandary arose as to what types of IDTs would be most likely to engender the affective conditions conducive to spoken interaction. The current sub-study grew out of this quandary, as a primary component of the initial design phase for the PDP prototype that will be executed in iterative stages; this study's aim was to discover which types of IDTs have induced positive affective reactions among participants and show potential to stimulate spoken interaction in order to create an evidence base for an activity handbook to be included in the PDP for FL teachers. Drama techniques abound, after all, varying in structure and content from simple role-plays in which pupils portray bickering siblings to activities that enlist the entire class to embody the conscience of a thief portrayed by the teacher herself.

Both researchers and practitioners utilize a variety of terms to describe activities of this nature, such as theatre games (Spolin, 1986) or process drama (Bowell \& Heap, 2013). For the purposes of this research, we employ the term improvisational drama techniques as it contains two key elements, namely improvisation and drama. Firstly, the activities must include an essence of drama, meaning that the participants take on roles in fictitious situations, which is built upon the notion that the initial safety of interacting behind a figurative mask can provide a stepping stone toward communication as themselves (Weber, 2019). Secondly, the activities must elicit spontaneous speech, as this improvisational element can prepare language learners for the spontaneity of real-life conversation, a central goal of this research.

The IDTs explored in this study fall under the category of small-scale forms of drama (Schewe, 2013 ) in that they are primarily conducted during separate class sessions. We focused on these forms as such activities can be integrated relatively easily into an existing curriculum with little preparation, thereby lowering the bar for teachers to implement them regularly. In this study, 
drama is intended to serve as a means of creating positive affective conditions, such as decreased anxiety or increased engagement, to in turn stimulate spoken interaction in the FL. The more often such activities can be implemented, evidence from former DitC student teachers suggests that these conditions will sustain themselves. Ultimately, as teachers gain in experience, it can be hoped that they will also integrate longer-term drama projects that can further augment the affective benefits on speaking the FL (Galante, 2018; Ryan-Scheutz \& Colangelo, 2004).

\section{Eliciting spoken interaction through improvisational drama}

The ability to interact verbally in a FL directly impacts a person's success in situations ranging from an everyday shop transaction to a high stakes UN convention. The classroom can serve as a rehearsal space for such interactions, as learners practice communicating as they would in real life (Barbee, 2014). For this reason, linguistic scholars worldwide widely support the Communicative Language Teaching (CLT) pedagogy (Dörnyei, 2012; Richards \& Rodgers, 2014); CLT promotes the development of communicative skills in realistic situations.

While Dutch national curriculum goals are supported by CLT-based teaching methodology (College voor Toetsen en Examens, 2015a, 2015b \& 2016), these communicative principles do not, however, appear to be widely implemented in Dutch FL secondary schools. West and Verspoor (2016), for example, observed that most teachers concentrated on grammar teaching, despite the fact that pupils appeared more engaged in CLT-oriented classrooms. In a large-scale study on speaking skills in English classes, Fasoglio and Tuin (2017) likewise found that teachers often avoid focusing on spoken interaction, citing a lack of resources for engaging activities as a primary reason. Haijma (2013) furthermore discovered when surveying the pupils themselves that the majority do not speak the FL in class, due to factors such as anxiety. This absence of a communicative focus also exists outside of the Netherlands, with similar findings reported in studies conducted in the United Kingdom (Hulse \& Owens, 2019), Turkey (Denkci-Akkas \& Coker, 2016), Japan (Humphries \& Burns, 2015) and Ecuador (Toro et al., 2019).

A possible force of change towards a more communication-oriented classroom lies in the integration of IDTs, as they can create the affective conditions essential to promoting spoken interaction according to the principles of CLT (Barbee, 2014). A central principle of CLT is the necessity of recognizing the affective aspect of language learning, according to Brandl (2008) who refers to Krashen's affective filter hypothesis (1984) - namely, when a learner feels confident and motivated, her affective filter lowers, and she is more likely to speak.

IDTs can stimulate positive affective reactions related to spoken interaction, by, for instance: 
- lowering anxiety and promoting self-confidence (Atas, 2015; Dunn \& Stinson, 2012; Galante, 2018; Rothwell, 2012; Sağlamel \& Kayaoğlu, 2013);

- stimulating enjoyment (Adebiyi \& Adalabu, 2013);

- engaging students (Kao \& O’Neill, 1998; Ntelioglou, 2012);

- cultivating creativity (Even, 2011; Gallagher, 2007); and

- engendering group bonding (Palechorou, 2012; Reed \& Seong, 2013).

The potential of IDTs lies in the fact that drama, in essence, allows learners to hide temporarily behind the mask of the fictional situation. Of course, performing in a scripted play invites participants into a fictional situation as well, but it is the improvisational component in IDTs that can prepare language learners for the spontaneity of real-life conversation. Putting on this figurative mask offers advantages by engendering a sense of safety that allows learners to shed anxiety (Arts, 2020; Atas, 2015; Sağlamel \& Kayaoğlu), and gain confidence to express themselves more freely. Weber (2019) noted in her study that increased speaking in drama activities appeared to carry over into other classroom interactions as well.

Drama activities can create an engaging classroom environment, thereby lowering learners' affective filters, which Heldenbrand (2003) distinguishes from the less enjoyable circumstances of completing rigid textbook exercises. Khajavy, Maclntyre and Barabadi (2018) found as well that enjoyment significantly increased Willingness to Communicate (WtC). MacIntyre and colleagues (1998) define their term WtC as an individual's inclination to speak in a communicative situation, which they connect to affective factors such as confidence. Also associated with WtC is engagement (Khajavy et al., 2018), described as "active participation in classroom activities" by Cawthon and Dawson $(2011$, p. 1 ) in relationship to their Drama for Schools (DFS) Program. Khajavy and colleagues (2018) furthermore mention creativity, exploration, play and problem-solving as behavioural by-products of positive emotions with reference to Frederikson (2013).

Finally, IDTs require a type of collaboration that can positively influence group dynamics in that there exists a collective excitement that takes place in the act of creative collaboration (Even, 2011; Gallagher, 2007; Russo Rastelli, 2006), particularly as many improvisational drama activities involve the class as a whole, including the teacher, who, for example, takes on the role of the eccentric guest looking for a room in a hotel lobby the pupils have created. Group bonding can be described as building an ensemble in the classroom (Hart et al., 2017), also of significance to intergroup climate, another building block of WtC (Maclntyre et al., 1998).

While evidence on the affective benefits of IDTs abounds, what is less known is which types of IDTs are most likely to engender the language learning benefits of drama techniques. The 
goal of the current study therefore strives to answer the question: What types of IDTs induce positive affective reactions among pupils and, as such, have the potential to stimulate spoken interaction in FL classrooms?

\section{Methodology}

Given the infinity of variables at play in any FL classroom, this study's aim was not to put forth a one-size-fits-all collection, but rather to offer FL teachers an evidence base upon which to build their repertoire of IDT teaching tools. The first step was to conduct a retrospective analysis of student teacher reflections $(n=67)$ from the first author's course DitC at HU University of Applied Sciences (HU). The coding scheme developed during this analysis was in turn applied to a literature review of 101 sources.

\subsection{Retrospective analysis of student teacher reflections}

The retrospective analysis involved revisiting five years of archived material from the DitC course, which is part of the master's-level English teacher training curriculum at HU. This master's degree qualifies student teachers to teach upper form secondary school. In the DitC course student teachers filmed themselves conducting an IDT with a group of pupils and in turn reflected upon the experience (written or recorded). To help them prepare, during the seven-week course student teachers participated in a variety of IDTs, discussed how to integrate drama into their own curriculum, and were given the option of trying out their chosen IDT before doing so with their secondary school pupils. Student teachers could choose an activity from among those practiced in class, which were selected from a course reader (Cousins et al., 2011), as well as the course book Drama Techniques (Maley \& Duff, 2005). Both sources focus on small-scale forms of drama (Schewe, 2013) as one of the assignment's aims was to let student teachers experience that IDTs can be easily integrated into their existing curricula. Alternatively they could find or create an IDT themselves. Student teachers were cautioned, however, that their chosen activity must place pupils in a fictitious situation and elicit spontaneous speech, and that even in the resource manuals provided, many activities fall outside of this criterion.

For this analysis, a data collection form was created, as shown in Table 1. Each student teacher was assigned a code to protect their anonymity. While 110 student teachers successfully completed this assignment within a five-year period, not all links to recorded reflections were still active, and six student teachers conducted activities at vocational schools or universities, which reduced the data set to 67 students who implemented IDTs in secondary school. 
Teacher: $5 \mathrm{~V}$

Source: written reflection

Class: university-track year 4, talkative, never has done anything related to drama, willing to learn

Activity: People, places, problems and things (from Drama Techniques)

Goal: not mentioned

Reflection: They were all willing to participate and some were even enthusiastic about it. Instructions were clear; pupils were able to list what I required of them although one of the groups struggled with the setting and theme they were given. I'm quite sure most pupils enjoyed the activity because most of them had a good laugh and some of them even took risks by using a funny voice or props. The pupils have used the English language a bit more than they usually do but the level of English displayed during the acts does not reflect their abilities very well. Setting a low standard of 30 seconds per person definitely helped to lower anxiety amongst pupils, motivating them to participate in a different type of activity. The positive atmosphere contributed to a positive result although the pupils deserved as much if not more credit than I do. Next time I will use an activity that requires them to speak more and a higher level of English. Setting an example would be a good addition as well.

Table 1: Example of Data Analysis Form

The data was analysed in iterative stages. The specific IDT types implemented were first calculated for frequency. Subsequently, the first researcher conducted a content analysis of the reflections and filtered out descriptions of pupils' affective reactions. A sample of these descriptions was independently analysed by the co-researchers as well as a researcher not involved in the study. Any discrepancies in coding, interpretation or terminology were discussed and reconciled. The first researcher in turn selected codes that most clearly matched relevant terminology from the body of research on affect in language learning: Enjoyment, Engagement, Group Bonding, Creativity, and Confidence.

For each of these positive affective reactions, a corresponding code was created to capture negative reactions, labelled as, for example, Absence of Enjoyment. Any reaction student teachers described that was not resolutely positive, such as neutral or mixed reactions, were also categorised under Absence.

Reactions were then coded by the first author. It is important to specify that the affective reactions that were analysed are based on behavioural and verbal manifestations as interpreted by the observing teacher. While these affective reactions are furthermore not necessarily mutually exclusive, the expressions of them suggest distinct underlying emotional processes. These expressions can be seen as building blocks of WtC (Maclntyre et al., 1998) as defined above.

Codes were then calculated for frequency. As student teachers sometimes repeated themselves, a code was only counted one time per reflection. While every student teacher 
who included an affective reaction was included in the calculation of frequency by code, only activities that generated predominantly positive affective reactions by two or more student teachers were added to a bank of activities to be used in the PDP.

The reflections were in turn analysed for possible relationships between affective reactions and inherent characteristics of the IDTs. An inherent characteristic refers to a specific quality of the IDT, such as eliciting particular vocabulary (Language Requirement) or allows participants to play specific characters, such as celebrities (Content). The aim was to discover the degree to which the activity itself was a determiner of its affective reactions. Inherent characteristic codes were generated inductively by the first author as follows: Language Requirements, Creativity Requirements, Format, Content, and Degree of Involvement.

\subsection{Literature review}

The subsequent literature review examined IDT-use in educational settings. While the PDP under design focuses on secondary school FL classes, this review included all education levels and subject areas with the supposition that an IDT can engender positive affective reactions in a variety of curricular environments. This review primarily involved a return to sources found during an earlier phase of the research project; while not intended to be exhaustive, the search was nonetheless augmented by additional sources during this review process.

Published works were considered appropriate for further review if they a) discussed concrete evidence of an affective reaction and b) referred to a specific IDT. Concrete evidence encompassed both studies presenting empirical data as well as sources that included anecdotal reflections from teachers. Reference to a specific IDT was either a description provided by the author or mention of an IDT that was recognizable by title (e.g. Hot Seating) due to its popularity among practitioners (e.g. Gallagher, 2007). Possible sources were sought from articles and books on the use of drama in education published after 2000 by using a snowball method.

Activities were subsequently evaluated for their potential to meet this study's criteria for an IDT, namely placing participants in a fictional situation and eliciting spontaneous spoken interaction. This is not to say that the participants themselves needed to speak. For instance, in van Hoesel's research project on the use of drama techniques to help students apply grammar concepts to verbal communication (2018), she had pupils in her German class create a tableau, such as angry football fans dismayed by the referee's decision, and in turn asked audience members to come up with their speech bubbles, as if they appeared in a comic strip. Such a technique can be effective in the early stages of integrating IDTs, as the spectators remove the pressure to speak from the performers (Even, 2011). 
If an activity did not directly meet this study's criteria as described but nonetheless appeared to be adaptable to the criteria, a notation was made with the possible adaption. In Narrative Pantomime (Palechorou \& Winston, 2012), for example, the teacher tells a story while pupils mime the actions, but it can be adapted so that pupils add in lines of dialogue.

Pupils' affective reactions as reported by the sources were catalogued, whether these were responses from the pupils themselves gathered through a measurement tool or in an informal anecdote, or behavioural manifestations of these emotions (e.g. laughing), as observed by a teacher or researcher. These affective reactions were assigned codes with the scheme which was developed during the retrospective analysis. Not all sources discussed pupils' reactions in direct relationship to specific IDTs, instead listing or describing the activities separately. If a source did discuss a relationship between the specific IDT and pupils' reactions, the source was further analysed for a possible connection between the inherent characteristics of the IDT and the affective reaction.

Subsequently, activities that were mentioned in sources that discussed predominantly positive affective reactions to IDTs were added to an activity handbook. Even if no direct link was made between the specific IDT and positive affective reactions, the activities were included in the handbook under the belief that the author mentioned the particular IDT as exemplary of the positive results they describe relating to IDTs as a whole. If the source discussed primarily absences of positive reactions to the IDTs, the activities in question were not included. Also excluded were activities by which the instructions could not be clearly gleaned from the source, or those that required a lengthy explanation, as it was decided that descriptions longer than approximately 200 words might preclude teachers from implementing the IDTs.

As the names for the same or strikingly similar IDTs vary widely among sources, such activities were counted as multiple instances of the same IDT. Tableau, Frozen Image, and Voices in the Head, for instance, were grouped together as one IDT because in all of these activities, participants freeze in a certain pose. While all variant titles are listed in the Appendix, in the handbook a single title was chosen for the sake of clarity, based on the most commonly used title or the one most clearly illustrating the activity.

It was decided that only one instance of a positive affective reaction was required for inclusion in the handbook among IDTs found in the literature review, while two instances were required for IDTs mentioned by student teachers. We considered a source as informal as a student teacher reflection required a greater burden of proof than a published document in which the IDT had likely undergone a more rigorous process of scrutiny. 
Additional steps were taken to transform this bank into a useable handbook for FL teachers in the Netherlands. For each IDT, an activity description was translated to Dutch, adapted from the source to meet IDT criteria. A recommended minimum language level was also added, utilising the Common European Framework of Reference, which categorises language proficiency on a scale of A1 to C2 (Council of Europe, 2018).

\section{Results}

This study's results consist of qualitative and quantitative data from a retrospective analysis of 67 student teacher reflections from the DiTC course, as well as a literature review of 101 sources. These two components collectively yielded 77 IDTs associated with positive affective reactions that can in turn form an evidence base for the subsequent research project.

\subsection{Retrospective analysis of student teacher reflections}

The retrospective analysis yielded results on the IDTs in terms of frequency of use, affective reactions, and inherent characteristics. A total of 88 IDTs were executed by 67 students.

Some IDTs proved particularly popular. Table 2 shows an overview of activities used more than once. A clear preference is evident for Dr. Know-it-All, which requires three to five individuals to sit in a horizontal line facing the audience. Collectively these participants comprise Dr. Know-it-All. The audience can ask this sage questions such as "Why is the sky blue?" and the doctor answers, but each participant can only speak one word at a time. The choppy answer may sound something like this: "Well - the - sky - is - blue - because - it - is - full - of blueberries." Student teachers also showed an inclination toward IDTs in which a picture served as a central element. Activities presented in the Drama Activities Reader (Cousins, De Jong \& Goodnight, 2011) were used most often, in 47 of the total 88 IDTs implemented, followed by activities from the course book Drama Techniques (Maley \& Duff, 2005), from which 22 were cited. In the remaining 19 cases, the activities were inspired by television programs or the student teachers themselves, or the origin was not specified. Table 2 also shows that no particular type of IDT was more likely to generate positive affective reactions than another. 
IDT

How often used

Positive affective reactions mentioned

\begin{tabular}{lll}
\hline Dr. Know it All & 9 & 7 \\
\hline Bringing a Picture to Life/Becoming a & 5 & 5
\end{tabular}

Picture/Mood Pictures

\begin{tabular}{lll}
\hline Park Bench & 4 & 4 \\
\hline I have to go & 3 & 3 \\
\hline Alibi & 3 & 2 \\
\hline A to Z & 2 & 2 \\
\hline Can't Say No & 2 & 2 \\
\hline Channel Hopping/Sports Commentary & 2 & 2 \\
\hline Charades & 2 & 2 \\
\hline Conflict Improvisation & 2 & 2 \\
\hline Split Exchanges & 2 & 2 \\
\hline Talk Show & 2 & 2 \\
\hline Trapped in an Elevator & 2 & 2 \\
\hline What am I holding? & 2 & 2 \\
\hline What's my problem? & 2 & 2
\end{tabular}

Table 2: Overview of IDTs implemented more than once

The activities elicited chiefly positive affective reactions, as evidenced in Table 3. Enjoyment was most often mentioned, by 47 student teachers. Among these, 16 reported that pupils requested to use IDTs more often; for example, one student teacher stated that "every lesson they ask me when we will do similar activities again." Under the codes Enjoyment, Engagement and Confidence it is noteworthy that 13 student teachers remarked on individual pupils exhibiting extraordinary positive behaviour they had seldom witnessed before, such as "I was surprised by the courage displayed by some of the very reluctant speakers." To a lesser extent, IDTs appeared to engender Group Bonding (16\%) and Creativity (10\%). Twenty-two IDTs implemented by student teachers became part of the handbook for the PDP, 12 of which overlapped with those from the literature review.

Absence of positive affective reactions was mentioned with significantly less frequency. Absence of Confidence appeared to serve as the largest barrier, stated by $19 \%$ of student teachers. What the reflections also revealed was that 6 of these 13 student teachers attributed Absence of Confidence to the presence of a camera, (as they were required to film themselves for their master's course), rather than to inherent characteristics of the IDTs. 


\section{Positive Affective Reactions}

\begin{tabular}{lll} 
Code & Frequency* & Example Excerpts from Reflections \\
\hline Enjoyment & $47(70 \%)$ & "laughing a lot;" "all said they really liked it; students very excited" \\
\hline Engagement & $30(45 \%)$ & $\begin{array}{l}\text { "one student decided he couldn't stand by anymore and jumped in to } \\
\text { support the prosecution team; everyone was actively engaged" }\end{array}$ \\
\hline Confidence & $21(31 \%)$ & $\begin{array}{l}\text { "students were very much at ease;" "seemed to forget their reluctance } \\
\text { to speak English during the activity" }\end{array}$ \\
\hline $\begin{array}{l}\text { Group } \\
\text { Bonding }\end{array}$ & $11(16 \%)$ & $\begin{array}{l}\text { "brought things out in open- healing," "group bonded with me and } \\
\text { each other" }\end{array}$ \\
\hline Creativity & $7(10 \%)$ & "used imagination;" "students were creative" \\
\hline
\end{tabular}

Absence of Positive Affective Reactions

\begin{tabular}{lll} 
Code & Frequency* & Example Excerpts from Reflections \\
\hline $\begin{array}{l}\text { Absence of } \\
\text { Confidence }\end{array}$ & $13(19 \%)$ & "a lot felt a bit awkward;" "camera made them shy" \\
\hline $\begin{array}{l}\text { Absence of } \\
\text { Creativity }\end{array}$ & $4(1 \%)$ & $\begin{array}{l}\text { "where they have shown to possess very creative minds in the past, } \\
\text { very little was shown today;" "some had very thin plots" }\end{array}$ \\
\hline $\begin{array}{l}\text { Absence of } \\
\text { Engagement }\end{array}$ & $2(0.3 \%)$ & $\begin{array}{l}\text { "not all students took it seriously; "some were less focused, on the } \\
\text { one hand that was a pity, on the other hand they were still talking" }\end{array}$ \\
\hline $\begin{array}{l}\text { Absence of } \\
\text { Enjoyment }\end{array}$ & $1(0.1 \%)$ & $\begin{array}{l}\text { "Students not as enthusiastic as in the first lesson, but I still think } \\
\text { they enjoyed it" }\end{array}$ \\
\hline
\end{tabular}

*Codes were tallied once per source, rather than per IDT.

Table 3: Pupils' affective reactions to IDTs from retrospective analysis

Reflections were in turn examined to ascertain the degree to which the inherent characteristics of an IDT appeared to be a factor contributing to its affective reactions. Student teachers made 43 comments related to inherent characteristics of the IDT, as shown in Table 4. Language Requirements were noted on 13 occasions -9 positively and 4 negatively. Some comments on language, however, were only indirectly associated with affect, such as the student teacher who noted that the IDT "challenges pupils to use spoken English at a level most have not tried before." Content was, in 8 out of 10 comments, reflected upon in a positive light. Pupils found it "hilarious to play a piece of fruit," for example. Student teachers also mentioned Format as an influential factor; one student teacher tried four different taskbased activities and felt this structural aspect made these IDTs succeed, as participants had a particular goal, such as trying to get the other characters in an improvisation to say the word "No." The Creativity Requirements of particular IDTs appeared both to inspire and inhibit pupils -4 student teachers remarked that their pupils struggled to come up with characters or settings. For 5 student teachers, the degree of involvement was a factor; 2 observed that their pupils enjoyed the audience participation element, yet in 2 other cases student teachers gave opposing opinions on IDTs that did not involve all pupils equally-one noting that a talk show host role placed too great a linguistic burden on one participant, and the other mentioning that in Freeze Improvisation, it put her pupils at ease that they could choose not to volunteer. In this IDT, an audience member can shout "Freeze!" and replace one of the actors. The audience then suggests a new scene inspired by the frozen pose. 


\begin{tabular}{llll}
$\begin{array}{l}\text { Inherent } \\
\text { Characteristic }\end{array}$ & IDT: Excerpt & $\begin{array}{l}\text { Positive } \\
\text { Comments }\end{array}$ & $\begin{array}{l}\text { Negative } \\
\text { Comments }\end{array}$ \\
\hline $\begin{array}{l}\text { Language } \\
\text { Requirements }\end{array}$ & $\begin{array}{l}\text { Charades: "I think they will remember these words } \\
\text { because they really had fun playing with them." }\end{array}$ & 9 & 4 \\
\hline $\begin{array}{l}\text { Creativity } \\
\text { Requirements }\end{array}$ & $\begin{array}{l}\text { Alternative Ending: "Story helped them use their } \\
\text { imagination." }\end{array}$ & 3 & 4 \\
\hline Format & $\begin{array}{l}\text { Sports Commentary: "All the players were dependent } \\
\text { on each other to complete the task." }\end{array}$ & 5 & 3 \\
\hline Content & $\begin{array}{l}\text { Reenacting a TV Series: "They were too focused on } \\
\text { how people acted in the series." }\end{array}$ & 8 & 2 \\
\hline $\begin{array}{l}\text { Degree of } \\
\text { Involvement }\end{array}$ & $\begin{array}{l}\text { Dr. Know-It-All: "Audience had fun thinking of silly } \\
\text { questions and watching Dr. Know it All struggle." }\end{array}$ & 4 & 1 \\
\hline Total & & $\mathbf{2 9 ( 6 7 \% )}$ & $\mathbf{1 4}$ (33\%)
\end{tabular}

Table 4: Comments on inherent characteristics of IDTs from retrospective analysis

Teacher-related factors, such as giving instructions, were also examined during the retrospective analysis; this data is not reported upon here as it falls outside the scope of the current study. These factors, as well as the teacher's degree of training in IDT-integration, can nonetheless be a key determiner of pupils' affective reactions (Borge, 2007), and this variable will be a central point of analysis in the next phase of this longitudinal research project.

\subsection{Literature review}

One hundred and one published sources were reviewed, among them journal articles (reports on empirical studies, as well as position papers) and books (ranging from practical resource materials to those offering a theoretical foundation for drama in education), primarily with a publication date in 2000 or later. Of the 101 published works found, 72 sources met the criteria above as evidence-based. Among these 72 sources, 34 distinct sources mentioned specific examples of IDTs; 27 of these were focused on FL learning, two on language arts in general, and the remaining five were related to a variety of other subjects.

Among these 34 sources, 66 different IDTs were identified as activities that (were suitable to) put participants in fictitious situations and stimulate spoken interaction, as well as being associated with positive affective reactions. The most commonly cited IDTs were variations on Tableau, found in 13 sources.

The DFS program, which grew out of a decade of research in Texas schools, produced a website (https://dbp.theatredance.utexas.edu/about/drama-schools), in which 36 IDTs were found. While their studies did not focus on language learning, many activities included variations for literacy lessons that were applicable to eliciting spoken interaction in a fictitious situation. In Obstacle Course, for instance, participants place objects such as chairs in a space, and through a series of questions, one pupil leads her blindfolded partner through the course. 
As suggested under variations on the site, this activity could be executed as characters negotiating their way through figurative obstacles.

Activities were then adapted as needed if a spoken interaction element could be added without fundamentally altering the activity. In Machine, for example, participants use movement and sound to collectively create a machine; in the handbook this IDT included the notation that participants can come up with lines of dialogue or include commentators describing the machine's purpose.

Affective reactions to IDTs were interpreted according to the codes created during the retrospective analysis. One additional code emerged during the literature review, namely Empathy, as authors repeatedly noted that through the IDTs participants expressed that they felt what another person might feel in that situation. DiNapoli (2007) in particular discussed empathy as a catalyst for language learning. With the introduction of this new code student teacher reflections were revisited for descriptions of Empathy, but none were found. Six instances of extraordinary behaviours were noted under Engagement, Enjoyment and Confidence; for example Palechorou and Winston (2012, p. 50) describe a shy girl who, after some encouragement, confidently took on the role of a kidnapper and "seemed an entirely different person." Table 5 displays the frequencies of affective reactions, as well as example from sources.

While some authors discussed the challenges experienced when implementing IDTs, only three authors discussed categorically negative reactions to IDTs (see Table 5). Borge (2007) noted Absence of Engagement and Absence of Group Bonding in her first-year German class, but when she implemented IDTs with upper-level groups her students responded that they enjoyed the activities. Kao and O'Neill (1998) likewise observed that the student who expressed an Absence of Confidence in response to a small-group IDT, exhibited more Confidence when participating more anonymously in a whole-class Tableau activity. 


\section{Positive Affective Reactions}

\begin{tabular}{lll} 
Code & Frequency* & Example Excerpts from Reflections \\
\hline Enjoyment & $14(58 \%)$ & $\begin{array}{l}\text { "SABINA: Do you think making you laugh is important for you in } \\
\text { terms of learning English? } \\
\text { BOY 2: Yes. Gotta learn happily" } \\
\text { (Chang and Winston 2012: 20). }\end{array}$ \\
\hline Creativity & $13(54 \%)$ & $\begin{array}{l}\text { "I think in drama we do imaginary things and I think that makes you } \\
\text { think more creatively about life" (Gallagher 2007: 82). }\end{array}$ \\
\hline $\begin{array}{l}\text { Group } \\
\text { Bonding }\end{array}$ & $11(46 \%)$ & $\begin{array}{l}\text { "Erene was more than satisfied to see these changes persist after the } \\
\text { conclusion of a project that had fostered a community of learners able } \\
\text { to work together and enjoy each other's company" (Palechorou \& } \\
\text { Winston 2012: 53). }\end{array}$ \\
\hline Empathy & $10(42 \%)$ & $\begin{array}{l}\text { "You experience what others are going through and you help give } \\
\text { suggestions, solutions" (Cahnnman-Taylor \& Souto-Manning 2010 } \\
\text { :145). }\end{array}$ \\
\hline Engagement & $10(42 \%)$ & $\begin{array}{l}\text { "What stayed with me most after my year-long observations in this } \\
\text { Drama-EAL classroom was the palpable energy and engagement that } \\
\text { was present throughout the course" (Ntelioglou 2012: 89). }\end{array}$ \\
\hline Confidence & $10(42 \%)$ & $\begin{array}{l}\text { "I was like a small kid and I didn't care about others' reactions" } \\
\text { (Sağlamel \& Kayağlu 2013: 390). }\end{array}$ \\
\hline
\end{tabular}

\begin{tabular}{|c|c|c|}
\hline \multicolumn{3}{|c|}{ Absence of Positive Affective Reactions } \\
\hline Code & Frequency* & Example Excerpts from Reflections \\
\hline $\begin{array}{l}\text { Absence of } \\
\text { Confidence }\end{array}$ & $1(4 \%)$ & $\begin{array}{l}\text { "Why couldn't I open my mouth? I think I was so afraid that my } \\
\text { classmates would laugh at my broken English" (Kao \& O'Neill 1998: } \\
\text { 113). }\end{array}$ \\
\hline $\begin{array}{l}\text { Absence of } \\
\text { Engagement }\end{array}$ & $1(4 \%)$ & $\begin{array}{l}\text { "The first-year students did not respond well to drama } \\
\text { activities... and increasingly refused to cooperate" (Borge 2007: 7). }\end{array}$ \\
\hline $\begin{array}{l}\text { Absence of } \\
\text { Group } \\
\text { Bonding }\end{array}$ & $1(4 \%)$ & $\begin{array}{l}\text { "These students also demonstrated reluctance to cooperate with other } \\
\text { class members who belonged to different course groups" (Borge } \\
\text { 2007: 7). }\end{array}$ \\
\hline
\end{tabular}

${ }^{*}$ Codes were tallied once per source, rather than per IDT.

Table 5: Pupils' affective reactions to IDTs from literature review

In 17 of the 34 sources, the authors made an explicit connection between at least one specific IDT and its affective reaction. Each of these IDTs were analysed for inherent characteristics in relation to the reaction. Format and Creativity Requirements were most often noted, followed by Degree of Involvement with seven comments. Language Requirements were mentioned in three cases and Content in two. Table 6 shows the frequency of comments referring to inherent characteristics, as well as examples. 


\begin{tabular}{llll}
$\begin{array}{l}\text { Inherent } \\
\text { Characteristic }\end{array}$ & Example IDT: Excerpt & $\begin{array}{l}\text { Positive } \\
\text { Comments }\end{array}$ & $\begin{array}{l}\text { Negative } \\
\text { Comments }\end{array}$ \\
\hline $\begin{array}{l}\text { Creativity } \\
\text { Requirements }\end{array}$ & $\begin{array}{l}\text { Artefacts: "'It can be anything you want it to be" (Hull } \\
\text { 2012: 40) }\end{array}$ & 11 & 0 \\
\hline Format & $\begin{array}{l}\text { Puppet Show: "The finger puppet show brought out } \\
\text { different aspects of the children's personalities" (Chang } \\
\text { \& Winston 2012: 22) }\end{array}$ & 11 & 0 \\
\hline $\begin{array}{l}\text { Degree of } \\
\text { Involvement }\end{array}$ & $\begin{array}{l}\text { Town Hall Meeting: "The formal, unequal relation } \\
\text { between the teacher and student had been changed in } \\
\text { the scene: the children became very active in the } \\
\text { conversation" (Kao \& O'Neill 1998: 110-111). }\end{array}$ & 7 & 0 \\
\hline $\begin{array}{l}\text { Language } \\
\text { Requirements }\end{array}$ & $\begin{array}{l}\text { Narrative Pantomime: "In being released from the } \\
\text { constraints of language, additional language learners } \\
\text { could express their thoughts through their bodies" } \\
\text { (Palechorou \& Winston 2012: 49). }\end{array}$ & 3 & 0 \\
\hline Content & $\begin{array}{l}\text { Im Restaurant: "The students responded well to } \\
\text { tension-creating dramatic devices...to rid themselves of } \\
\text { the 'poisoned' red wine glass" (Borge 2007: 6-7). }\end{array}$ & 2 & \\
\hline Total & & $\mathbf{3 4}$ (100\%) & $\mathbf{0}$ (0\%)
\end{tabular}

Table 6: Comments on inherent characteristics of IDTs from literature review

The remaining authors shared their data or anecdotes separately from the IDT descriptions. Sağlamel \& Kayaoğlu (2013), for example, listed their activities in an appendix, and elsewhere in the article shared their results that indicated increased confidence. For these sources it was therefore not possible to analyse the inherent characteristics of the IDTs in direct relation to their affective reactions.

\section{Discussion \& conclusion}

The question driving this study was: What types of IDTs induce positive affective reactions among participants and, as such, show potential to stimulate spoken interaction in the foreign language classroom? The answer, tersely put, is many. This was evident in both the relatively homogenous sample of Dutch secondary school student teachers of English and among published researchers and practitioners on six continents operating in classrooms ranging in subject from Biology to Greek and with pupils from kindergarten to university.

\subsection{Discussion}

Frequency of IDT-integration was a primary factor under analysis in this study. Some IDTs were implemented notably often. Tableau-related activities appeared most often in published sources, and Dr. Know-it-All among student teachers. This is not to say that these IDTs are more effective per se, but that they have a wider evidence base due to the fact that they were chosen more often within this research context. Researchers and practitioners from the literature review may have selected IDTs they had found in widely-available resource materials or that had been passed down to them through years of drama experience. The 
student teachers commonly chose IDTs that were close at hand-those from the course reader and the required textbook. The ubiquitous Dr.-Know-it-All was also one of the IDTs that had been demonstrated during class every year, which underscores the notion that training teachers in the techniques is a key catalyst to their implementation.

The degree to which inherent characteristics of IDTs contributed to pupils' affective reactions was also a point of scrutiny. Yet by examining these characteristics more closely it becomes apparent that they are not necessarily unique to the IDTs in question, nor are the IDTs themselves immutable. In an interview with Kathryn Dawson, co-creator of the DFS program, she shared an anecdote in which she had used Tableau in a workshop conducted in BosniaHerzegovina. Dawson commented that this IDT was imminently effective because individuals of all language levels could participate fully (personal communication, 25 April, 2019). The (absence of) Language Requirements in this IDT clearly contributes to its strength, yet this characteristic can be incorporated into many other activities as well. The malleability of an IDT thus creates challenges in drawing conclusions on inherent characteristics.

While not all IDTs examined in this study produced sufficient evidence of positive affective reactions, a substantial majority of them did, regardless of their characteristics. The one common denominator among activities selected for incorporation in the handbook is that participants are placed in a fictional world, spoken interaction is elicited, and that the IDT is evaluated positively by student teachers and/or in published sources. The wide array of IDTs that comprise the handbook is perhaps only the tip of the iceberg of activities that meet such criteria, yet these activities are a starting point for an evidence base that is at the very least anecdotal and in some cases empirically grounded.

This study suggests that it is not necessarily the type of IDT that is a primary determiner of its affective reactions, but also the teacher who implements it, combined with the ever-changing class chemistry on any given school day. One student teacher who experienced enthusiasm among her pupils with Alibi, for example, mentioned that she preceded the IDT with a warmup activity. In Alibi the teacher announces that a crime has been committed, such as robbing a pie shop. The pupils work in pairs to come up with an alibi. They are subsequently questioned separately by detectives, who must decide whom to believe. Another student teacher who implemented Alibi with less effectiveness reflected that she should have given an example and made her instructions more clear. A key point of analysis in the PDP under design will be the interplay between teacher behaviours that influence affective factors so that a set of heuristics for effective implementation can be developed. Borge (2007), for instance, discovered the need for research-based guidelines for effective implementation after experiencing mixed results with her university-level German classes. 


\subsection{Limitations}

Two primary factors limit the validity of this study's outcomes. One factor is that both the retrospective analysis and the literature review are ex post facto investigations of previously collected evidence. A second issue is possible bias among student teachers reporting positive reactions.

This research was conducted on instances of IDT implementation that took place before the actual study began-in diverse conditions in which data collection could not be guided nor variables controlled. This is a reality intrinsic to ex post facto research (Cohen et al., 2011), which limits the analysis of one-to-one relationships between IDTs and affective reactions. The sizeable data set-five years of student teacher reflections $(n=67)$ and 101 published sources-nonetheless allowed for a cautious supposition that diverse types of IDTs can engender positive affective reactions in a variety of classroom situations.

In regard to reporting bias in the retrospective analysis, it is important to remain cognizant of the fact that student teachers may have felt inclined to augment the positivity of their experiences with IDT since their reflection would be graded. This potential bias was, however, mitigated by the fact that they also included a video of IDTs they reflected upon, whereby they could not freely invent fiction about pupils' reactions. Among published sources, discussions of affective reactions were also almost universally positive, which corroborates the reported experiences among student teachers, although this is not to say these researchers and practitioners did not also face setbacks with particular IDTs along the way.

\subsection{Implications}

This study has implications both for successive phases of this longitudinal project, as well as for further research on IDTs. Participating teachers in the PDP under design will be asked to integrate IDTs into a FL class at least twice between monthly sessions. While they will be encouraged to choose and adapt activities as they see fit for their teaching practice, this study has shown that it would behoove the further development of an evidence base to have participants $\neg-$ in both this subsequent study or elsewhere - implement a stipulated set of activities in order to generate more robust data on specific IDTs. Challenges in conducting the retrospective analysis can play a role in designing data collection tools on types of IDTs. Teachers can keep a logbook, for example, of each instance of IDT implementation; it became clear when analysing student teacher reflections that a logbook must explicitly elicit information from teachers on their justification for choosing, adapting or creating specific IDTs and in turn ask them to reflect on the degree to which the IDT choice was a factor in stimulating positive affective reactions. 
If other researchers and practitioners are explicit about their IDT choices and subsequently, the relationship between chosen activities and pupils' reactions, the evidence base will further grow, allowing for the possible identification of more salient characteristics among particular IDTs that elicit positive affective reactions - and under what classroom conditions.

The dynamics inherent in education furthermore endure as a challenge in conducting research in this setting, yet the classroom is the only ecologically valid environment in which to test IDTs. With these myriad variables, long-term research is essential, in which each teacher's integration of IDTs over time is carefully documented and analysed through qualitative methods such as reflective logbooks, interviews and observations, in order to construct thick descriptions of how these activities truly function within the FL teaching practice and in turn strengthen or adapt conclusions that develop.

\subsection{Conclusion}

This study lends credence to the conception that it could in fact be the essence of drama that generates positive affective reactions, rather than the specific type of IDT-the essence being an invitation to enter a fictional world, combined with the improvisational element that readies learners for spontaneous interactions. After experimenting with Alibi, one student teacher mused, "It is so remarkable that when we are young we all want to be the police officer ... and we lose that when we are older." Maybe we don't - and it is through this opportunity to take on any sort of role, be it talk show contestant or football hooligan, that we find the courage to converse with each other until we can shed the mask and speak up as ourselves. And if we don't know all the words we want to say, our experience with IDTs has shown us that a bit of miming can take care of the rest.

\section{Bibliography ${ }^{1}$}

*Adebiyi, A. A., \& Adelabu, B. (2013). Improvisation as a tool for developing students' competence in English language: A study of the federal university of agriculture, Abeokuta, Nigeria. International Journal of Education and Research, 1(1), 195-211.

Arnold, J. (2018, November). Affect in language learning: A map of the terrain. Keynote address at the Language Education and Emotions Conference. Antwerp.

*Arts, A. (2020). If you can't say it, take a puppet. Scenario, 14(1), 98-102.

\section{https://doi.org/10.33178/scenario.14.1.6}

\footnotetext{
${ }^{1}$ The sources highlighted by * include the evidence-based IDTs referred to in the article, as well indicated in shorthand in Appendix A.
} 
Atas, M. (2015). The reduction of speaking anxiety in EFL learners through drama techniques.

Procedia-Social and Behavioral Sciences, 176, 961-969.

https://doi.org/10.1016/j.sbspro.2015.01.565

Barbee, M. (2014). Furthering the case for drama in the second language classroom. Polyglossia, 26, 13-26.

*Borge, S. (2007). The use of drama activities in teaching German in a third-level classroom. Scenario, 1(1), 1-24. https://doi.org/10.33178/scenario.1.1.1

Boudreault, C. (January 2010). The benefits of drama in the ESL/EFL classroom. The Internet TESL Journal, 14(1), 1-5. http://iteslj.org/Articles/Boudreault-Drama.html

Bowell, P., \& Heap, B. S. (2013). Planning process drama: enriching teaching and learning ( $2^{\text {nd }}$ ed.). Routledge. https://doi.org/10.4324/9780203125335

Brandl, K. (2008). Principles of communicative language teaching and task-based instruction. Communicative language teaching: Putting principles to work. Pearson Longman.

*Cahnmann-Taylor, M., \& Souto-Manning, M. (2010). Teachers act up! Creating multicultural learning communities through theatre. Teachers College Press.

*Cannon, A. (2017). When statues come alive: Teaching and learning academic vocabulary through drama in schools. TESOL Quarterly, 51(2), 383-407. https://doi.org/10.1002/tesq.344

Cawthon, S. W., \& Dawson, K. M. (2011). Drama-based instruction and educational research: Activating praxis in an interdisciplinary partnership. International Journal of Education \& the Arts, 12(17), 1-21. http://www.ijea.org/v12n17/index.html

*Chang, L.-Y. S., \& Winston, J. (2012). Using stories and drama to teach EFL at primary level. In J. Winston (Ed.), Second language learning through drama (pp. 15-30). Routledge.

${ }^{*}$ Cheng, A. Y., \& Winston, J. (2012). Second language learning and cultural empowerment: Teaching Shakespeare in Taiwan. In J. Winston (Ed.), Second language learning through drama (pp. 104115). Routledge.

Cohen, L., Manion, L., \& Morrison, K. (2011). Research methods in education ( $7^{\text {th }}$ ed.). Routledge.

College voor Toetsen en Examens (2015a). Moderne vreemde talen havo 2017: Syllabus Centraal Examen Arabisch, Duits, Engels, Frans, Russisch, Spaans, Turks. Versie 2, juni 2015. CvTE. [Syllabus for the Central Exams in Arabic, German, English, French, Russian, Spanish, Turkish]. https://www.examenblad.nl/examenstof/syllabus-2017-moderne-vreemde3/2017/f=/moderne vreemde talen havo 2 versie 2017.pdf

College voor Toetsen en Examens (2015b). Moderne vreemde talen vwo 2017: Syllabus Centraal Examen Arabisch, Duits, Engels, Frans, Russisch, Spaans, Turks. Versie 2, juni 2015. CvTE. [Syllabus for the Central Exams in Arabic, German, English, French, Russian, Spanish, Turkish]. https://www.examenblad.nl/examenstof/syllabus-2017-modernevreemde/2017/vwo/f=/mvt vwo 2 versie 2017.pdf

College voor Toetsen en Examens (2016). Moderne vreemde talen vmbo 2018: Syllabus Centraal Examen. Versie 2, juni 2016. CVTE. [Syllabus for the Central Exams in Arabic, German, English, 
French, Russian, Spanish, Turkish]. https://www.examenblad.nl/examenstof/syllabus-2018moderne-vreemde-3/2018/vmbo-bb/f=/moderne vreemde talen vmbo 2 versie 2018.pdf

Council of Europe. (2018). Common European Framework of Reference for languages: Learning, teaching, Assessment: Companion Volume with New Descriptors.

https://rm.coe.int/CoERMPublicCommonSearchServices/documentAccessError.jsp?url=http://rm. coe.int:80/CoERMPublicCommonSearchServices/sso/SSODisplayDCTMContent?documentld=0900 $\underline{00168074 a 4 \mathrm{e} 2}$

Cousins, K., De Jong, F., \& Goodnight, K. (2011). Drama activities reader. (Unpublished manuscript)

Denkci-Akkas, F., \& Coker, B. (2016). The use of communicative approach in 9th grade ESL classes. Eurasian Journal of Educational Research, 65, 71-90. https://doi.org/10.14689/ejer.2016.65.05

Dewaele, J-M., Witney, J., Saito, K., \& Dewaele, L. (2018). Foreign language enjoyment and anxiety: The effect of teacher and learner variables. Language Teaching Research, 22(6), 676-697. https://doi.org/10.1177/1362168817692161

*DiNapoli, R. (2009). Using dramatic role-play to develop emotional aptitude. International Journal of English Studies, 9(2), 97-110.

Dörnyei, Z. (2013). Communicative language teaching in the twenty-first century: The principled communicative approach. In J. Arnold \& T. Murphy (Eds.), Meaningful Action (pp. 161-171). Cambridge University Press.

*Dunn, J., \& Stinson, M. (2011). Not without the art!! The importance of teacher artistry when applying drama as pedagogy for additional language learning. Research in drama education, 16(4), 617-633. https://doi.org/10.1080/13569783.2011.617110

*Even, S. (2020). Presence and unpredictability in teacher education. Scenario, 14(1), 1-10. https://doi.org/10.33178/scenario.14.1.1

Even, S. (2011). Drama grammar: Towards a performative postmethod pedagogy. Language learning Journal, 39(3), 299-312. https://doi.org/10.1080/09571736.2010.543287

Fasoglio, D., \& Tuin, D. (2017). Eindniveau gespreksvaardigheid Engels in het voortgezetonderwijs. [Secondary school attainment levels for English spoken interaction]. SLO. https://slo.nl/@4929/eindniveau/

Fredrickson, B. L. (2013). Updated thinking on positivity ratios. American Psychologist, 68, 814-822. https://doi.org/10.1037/a0033584

Galante, A. (2018). Drama for L2 speaking and language anxiety: Evidence from Brazilian EFL learners. RELC Journal, 49(3), 273-289. https://doi.org/10.1177/0033688217746205

*Galante, A., \& Thomson, R. L. (2017). The effectiveness of drama as an instructional approach for the development of second language oral fluency, comprehensibility, and accentedness. TESOL Quarterly, 51(1), 115-142. https://doi.org/10.1002/tesq.290

*Gallagher, K. (2007). Theatre of urban: Youth and schooling in dangerous times. University of Toronto Press. 
*Göksel, E. (2019). Playing with possibilities: Drama and core French in the Montessori elementary classroom in British Columbia, Canada. Scenario, 13(1), 1-20.

https://doi.org/10.33178/scenario.13.1.1

Haijma, A. (2013). Duiken in een taalbad; onderzoek naar het gebruik van doeltaal als voertaal. [Diving into a language bath: Research on the use of target language as language of communication]. Levende Talen Tijdschrift, 14(3), 27-40.

*Hart, J., Onuscheck, M., \& Christel, M. T. (2017). Acting it out: Using drama in the classroom to improve student engagement, reading and critical thinking. Routledge.

https://doi.org/10.4324/9781315559513

Heldenbrand, B. (2003). Drama techniques in English language learning. Korea TESOL Journal, 6(1), 27-37.

*Hull, D. (2012). Theatre, language learning and identity (1): Empowering additional language learners through theatre in education. In J. Winston (Ed.), Second language learning through drama (pp. 31-41). Routledge.

Hulse, B., \& Owens, A. (2019). Process drama as a tool for teaching modern languages: Supporting the development of creativity and innovation in early professional practice. Innovation in language learning and teaching, 13(1), 17-30. https://doi.org/10.1080/17501229.2017.1281928

Humphries, S., \& Burns, A. (2015). 'In reality it's almost impossible': CLT-oriented curriculum change. ELT Journal 69(3), 239-248. https://doi.org/10.1093/elt/ccu081

*Kao, S.-M., \& O'Neill, C. (1998). Words into worlds: Learning a second language through process drama. Ablex.

Khajavy, G. H., Maclntyre, P. D., \& Barabadi, E. (2018). Role of the emotions and classroom environment in willingness to communicate: Applying doubly latent multilevel analysis in second language acquisition research. Studies in Second Language Acquisition, 40(3), 605-624. https://doi.org/10.1017/S0272263117000304

Krashen, S. (1984). The natural approach: Language acquisition in the classroom. Prentice Hall.

*Lenters, K., \& Smith, C. (2018). Assembling improv and collaborative story building in language arts class. The Reading Teacher, 72(2), 179-189. https://doi.org/10.1002/trtr.1689

MacIntyre, P. D., Dörnyei, Z., Clément, R., \& Noels, K. A. (1998). Conceptualizing willingness to communicate in a L2: A situational model of L2 confidence and affiliation. The Modern Language Journal, 82(4), 545-562. https://doi.org/10.1111/j.1540-4781.1998.tb05543.x

*Macy, L. (2009). Using a 'drama eye' to plan an integrated language arts program. International Journal of Drama in Education, 1, 1-23.

Maley, A., \& Duff, A. (2005). Drama techniques. A resource book of communication activities for language teachers ( $3^{\text {rd }}$ ed.). Cambridge University Press.

*McGeoch, K. (2012). Digital storytelling, drama and second language learning. In J. Winston (Ed.), Second language learning through drama (pp. 116-133). Routledge. 
*Nfor, S. (2018). Improving communicative competence through mime: Bringing students 'out-ofschool' literacy practices into Japanese university EFL oral communication classes. Scenario, 12(2), 13-29. https://doi.org/10.33178/scenario.12.2.2

*Ntelioglou, B. Y. (2012). Insights from a drama-EAL classroom. In J. Winston (Ed.), Second language learning through drama (pp. 81-91). Routledge.

*Palechorou, E., \& Winston, J. (2012). Theatre, language learning and identity (1): Empowering additional language learners through classroom drama projects. In J. Winston (Ed.), Second language learning through drama (pp. 42-53). Routledge.

*Piazzoli, E., \& Kubiak, J. (2019). 'The only learning I'm going to get': Students with intellectual disabilities learning a second language through performative pedagogy. Scenario, 13(1), 21-41. https://doi.org/10.33178/scenario.13.1.2

* Privas-Bréauté, V. (2019). Drama activities in a French undergraduate business school to manage speaking anxiety in English. Scenario, 13(2), 154-167. https://doi.org/10.33178/13.2.10

*Reed, J., \& Seong, M.-H. (2013). Suggestions for an effective drama-based EFL course at a Korean university. Journal of Pan-Pacific Association of Applied Linguistics, 17(2), 91-106.

Richards, J. C., \& Rodgers, T. S. (2014). Approaches and methods in language teaching (3 ${ }^{\text {rd }}$ ed.). Cambridge University Press.

*Rothwell, J. (2012). Drama and languages education: Authentic assessment through process drama. In J. Winston (Ed.), Second language learning through drama (pp. 54-68). Routledge.

Russo Rastelli, L. (2006). Drama in language learning. Encuentro, 16, 82-94.

*Ryan-Scheutz, C., \& Colangelo, L. M. (2004). Full-Scale theater production and foreign language learning. Foreign Language Annals, 37(3), 374-385. https://doi.org/10.1111/i.19449720.2004.tb02696.x

*Sağlamel, H., \& Kayaoğlu, M. N. (2013). Creative drama: A possible way to alleviate foreign language anxiety. RELC Journal, 44(3), 377-394. https://doi.org/10.1177/0033688213500597

Schewe, M. (2013). Taking stock and looking ahead: Drama pedagogy as a gateway to a performative teaching and learning culture. Scenario, 7(1), 5-27. https://doi.org/10.33178/scenario.7.1.2

*Schewe, M., \& Woodhouse, F. (2018). Performative foreign language didactics in progress: About still images and the teacher as 'Formmeister' (form master). Scenario, 12(1), 53-69.

https://doi.org/10.33178/scenario.12.1.4

*Seppänen, S., Tiippana, K., Jääskeläinen, I., Saari, O., \& Toivanen, T. (2019). Theater improvisation promoting interpersonal confidence of student teachers: A controlled intervention study. The European Journal of Social \& Behavioural Sciences, 24(1), 2770-2788.

https://doi.org/10.15405/ejsbs.244

Spolin, V. (1986). Theatre games for the classroom: A teacher's handbook ( $1^{\text {st }}$ ed.). Northwestern University Press. 
*Stinson, M., \& Freebody, K. (2006). The DOL project: The contributions of process drama to improved results in English oral communication. Youth Theatre Journal, 20(1), 27-41. https://doi.org/10.1080/08929092.2006.10012585

Toro, V., Camacho-Minuche, G., Pinza-Tapia, E., \& Paredes, F. (2019). The use of the communicative language teaching approach to improve students' oral skills. English Language Teaching, 12(1), 110-118. https://doi.org/10.5539/elt.v12n1p110

*Trimmis, K. P., \& Kalogirou, K. (2018). Performative archaeology: Exploring the use of drama in archaeology teaching and practice. Scenario, 12(2), 30-45.

https://doi.org/10.33178/scenario.12.2.3

Van Batenburg, E. S. L., Oostdam, R., Van Gelderen, A.J.S., Fukkink, R. G., \& De Jong, N. H. (2020). Evaluating opportunities in Dutch EFL course books for developing pre-vocational learners' oral interactional ability. Language Teaching Research, 24(4), 434-455. https://doi.org/10.1177/1362168818804258

*Van Hoesel, P. (2018). Dramatisch grammaticaonderwijs? Het effect van dramapedagogisch grammaticaonderwijs op grammaticale beheersing [Dramatic grammar education? The effect of drama-pedagogical grammar education on grammar mastery]. Levende Talen Magazine, 105(1), 5-9.

*Weber, S. (2019). Performance for introverts? Discourse evidence for students' collaborative shaping of social space. Scenario, 13(2), 139-156. https://doi.org/10.33178/scenario.13.2.9

West, L., \& Verspoor, M. (2016). An impression of foreign language teaching approaches in the Netherlands. Levende Talen Tijdschrift, 17(4), 26-36. 
Appendix: Bank of evidence-based IDTs from published sources and retrospective analysis of student teacher reflections

Complete descriptions of these activities can be found (in Dutch) through this link:

https://canvas.hu.nl/courses/11057/pages/handige-materialen

\begin{tabular}{|c|c|c|}
\hline IDT & $\begin{array}{l}\text { Evidence from } \\
\text { retrospective analysis }\end{array}$ & $\begin{array}{l}\text { Evidence from literature } \\
\text { review** }\end{array}$ \\
\hline A to $Z$ & $\begin{array}{l}\text { Two or more student } \\
\text { teachers }\end{array}$ & \\
\hline Advertising Design Pitch & & DFS/Privas-Bréaute \\
\hline Alibi & $\begin{array}{l}\text { Two or more student } \\
\text { teachers }\end{array}$ & Ryan-Scheutz \& Colangelo \\
\hline Alter Ego Panel Discussion & & Even \\
\hline $\begin{array}{l}\text { Alternative Ending /Create the } \\
\text { Beginning \& Ending }\end{array}$ & One student teacher & Saglamel \& Kayaouglu \\
\hline $\begin{array}{l}\text { Bringing a picture to life/Mood } \\
\text { Pictures/Becoming a } \\
\text { Picture/Living } \\
\text { Portraits/Pretend to be } \\
\text { Somebody in the Picture }\end{array}$ & $\begin{array}{l}\text { Two or more student } \\
\text { teachers }\end{array}$ & DFS/Saglamel \& Kayaouglu \\
\hline Bus Trip Role-Play & & Kao \& O’Neill \\
\hline Can't say no & $\begin{array}{l}\text { Two or more student } \\
\text { teachers }\end{array}$ & \\
\hline Car Towing & & Borge \\
\hline Charades & $\begin{array}{l}\text { Two or more student } \\
\text { teachers }\end{array}$ & Nfor/Trimmis \& Kalogirou \\
\hline Collective Drawing & & DFS/Hart et al./Hull \\
\hline Complete the Image & & DFS/Cahnmann-Taylor \\
\hline $\begin{array}{l}\text { Channel-hopping/Sports } \\
\text { Commentary }\end{array}$ & $\begin{array}{l}\text { Two or more student } \\
\text { teachers }\end{array}$ & \\
\hline Come, My Friends & & Cahnmann-Taylor \\
\hline Conflict Improvisation & $\begin{array}{l}\text { Two or more student } \\
\text { teachers }\end{array}$ & \\
\hline Conscience Alley & & $\begin{array}{l}\text { DFS/Macy/Reed \& Seong/Trimmis } \\
\text { \& Kalogirou }\end{array}$ \\
\hline Desire Ball & & Cheng \& Winston \\
\hline Distractions & & Ryan-Scheutz \& Colangelo \\
\hline Dr. Know-it-All & $\begin{array}{l}\text { Two or more student } \\
\text { teachers }\end{array}$ & \\
\hline $\begin{array}{l}\text { Elaborating on a textbook } \\
\text { dialogue/story }\end{array}$ & & $\begin{array}{c}\text { DiNapoli/Stinson \& } \\
\text { Freebody/Chang \& } \\
\text { Winston/Weber }\end{array}$ \\
\hline Elevator improvisation & $\begin{array}{l}\text { Two or more student } \\
\text { teachers }\end{array}$ & \\
\hline Everybody Do! (as characters) & & DFS \\
\hline
\end{tabular}




\begin{tabular}{|c|c|c|}
\hline $\begin{array}{l}\text { Exploding Atom/Stand in a Line } \\
\text { (as characters) }\end{array}$ & & DFS \\
\hline Exploration/Adventure & & DFS \\
\hline Expressions out of Place & & Ryan-Scheutz \& Colangelo \\
\hline Freeze Improv & One student teacher & Seppänen \\
\hline Fruit Bowl & One student teacher & Reed \& Seong \\
\hline Gift Giving & & DFS \\
\hline Gossip Mill & & Macy \\
\hline $\begin{array}{l}\text { Guided Imagery (as preparation } \\
\text { for improvisation) }\end{array}$ & One student teacher & DFS \\
\hline Handshakes & One student teacher & DFS \\
\hline Hot Seating & & $\begin{array}{l}\text { DFS/Göksel/Macy/Lenters \& } \\
\text { Smith/Reed \& Seong/ } \\
\text { Gallagher/Rothwell/Trimmis \& } \\
\text { Kalogirou }\end{array}$ \\
\hline I don't understand! & & Ryan-Scheutz \& Colangelo \\
\hline I have to go & $\begin{array}{l}\text { Two or more student } \\
\text { teachers }\end{array}$ & \\
\hline Im Restaurant/At a Restaurant & & Borge/ Saglamel \& Kayaouglu \\
\hline In the Manner of the Adverb & & DFS/ Ryan-Scheutz \& Colangelo \\
\hline Invisible Balls & & DFS \\
\hline $\begin{array}{l}\text { Machine (participants describe } \\
\text { what machine can do, give the } \\
\text { machine instructions) }\end{array}$ & & DFS/Cahnmann-Taylor \\
\hline Making a Complaint & & Saglamel \& Kayaouglu \\
\hline Mantle of the Expert & & $\begin{array}{l}\text { McGeoch,/Palechorou/Trimmis \& } \\
\text { Kalogirou }\end{array}$ \\
\hline Meet and Greet & & Borge \\
\hline Mime Rhyme & & DFS \\
\hline $\begin{array}{l}\text { Monster Tag (with a line of } \\
\text { dialogue) }\end{array}$ & & Lenters \& Smith \\
\hline Mother/Father, Son/Daughter & & Galante \& Thompson \\
\hline $\begin{array}{l}\text { Multi-lingual Counting (as } \\
\text { characters) }\end{array}$ & & DFS \\
\hline $\begin{array}{l}\text { Narrative Pantomime (with } \\
\text { added dialogue or having } \\
\text { students narrate) }\end{array}$ & & $\begin{array}{l}\text { DFS/Chang \& } \\
\text { Winston/Palenchorou \& } \\
\text { Winston/Adebiyi \& Adelabu }\end{array}$ \\
\hline $\begin{array}{l}\text { Obstacle Course (in an imaginary } \\
\text { setting), Minefield }\end{array}$ & & DFS/ Ryan-Scheutz \& Colangelo \\
\hline Objects of Character & & DFS \\
\hline Park Bench & $\begin{array}{l}\text { Two or more student } \\
\text { teachers }\end{array}$ & \\
\hline Puppet Show & & Arts/Chang \& Winston \\
\hline Rabbit/elephant/airplane & & DFS \\
\hline
\end{tabular}




\begin{tabular}{|c|c|c|}
\hline Rainbow of Desire & & Cahnmann-Taylor/Gallagher \\
\hline Real \& Ideal Images & & DFS/Cahnmann-Taylor \\
\hline Recipe for.... & & DFS \\
\hline Sales Pitch & & Kao \& O’Neill \\
\hline Sculptor/Clay & & $\begin{array}{l}\text { DFS/Cahnmann- } \\
\text { Taylor/Cannon/Cheng \& } \\
\text { Winston }\end{array}$ \\
\hline Shoplifting Witness/Detectives & & $\begin{array}{l}\text { Saglamel \& Kayaouglu / } \\
\text { Palechorou \& Winston }\end{array}$ \\
\hline Speaking Objects & & Trimmis \& Kalogirou \\
\hline Split Exchanges & $\begin{array}{l}\text { Two or more student } \\
\text { teachers }\end{array}$ & \\
\hline Sports pantomime & & Kao \& O’Neill \\
\hline Status Improvisation & & Seppänen et al., Hart et al. \\
\hline $\begin{array}{l}\text { Tableau/Snapshots/Group } \\
\text { Emotion/Show Us/Frozen } \\
\text { Image/Voices in the Head/Still } \\
\text { Image }\end{array}$ & & $\begin{array}{l}\text { DFS/Van Hoesel/Macy/Piazzolli \& } \\
\text { Kubiak/Schewe \& } \\
\text { Woodhouse/Reed \& } \\
\text { Seong/Ntelioglou/Cheng \& } \\
\text { Winston/McGeoch/Hart et } \\
\text { al./Cahnmann-Taylor/Kao \& } \\
\text { O'Neill }\end{array}$ \\
\hline Talk Show & One student teacher & DFS/Kao \& O’Neill \\
\hline This Setting Needs... & & DFS \\
\hline Thought Tracking & & $\begin{array}{l}\text { Göksel/Macy/Palechorou \& } \\
\text { Winston/Reed \& Seong/Cheng } \\
\text { \& Winston }\end{array}$ \\
\hline Tour of a Space (as characters) & & DFS \\
\hline Town Hall Meeting & & DFS/Kao \& O’Neill \\
\hline Train Station Small Talk & & Weber \\
\hline Travel/Time Machine & & DFS \\
\hline Trial/Courtroom & One student teacher & DFS/Kao \& O’Neill \\
\hline Turning down someone for a date & & Adebiyi \& Adelabu \\
\hline Two Revelations & & DFS \\
\hline $\begin{array}{l}\text { What am I holding?/ Artefacts } \\
\text { (reading/writing } \\
\text { variation)/This is not a... }\end{array}$ & $\begin{array}{l}\text { Two or more student } \\
\text { teachers }\end{array}$ & DFS/Hull/Privas-Bréauté \\
\hline What's my problem? & $\begin{array}{l}\text { Two or more student } \\
\text { teachers }\end{array}$ & \\
\hline What's the Story & & DFS \\
\hline $\begin{array}{l}\text { Writing in Role (following by } \\
\text { improvisation) }\end{array}$ & & DFS/Macy/Hart et al. \\
\hline Yes, And (as characters) & & DFS \\
\hline
\end{tabular}


Goodnight, van Beuningen, de Graaff: Perfect disguises

**A shorthand version of these sources is listed below. Complete bibliographic information can be found in the reference list, with the exception of DFS, which refers to the Drama for Schools program. Their website of activities can be found here:

https://dbp.theatredance.utexas.edu/teaching strategies 